\title{
High-resolution satellite turbidity and sea surface temperature observations of river plume interactions during a significant flood event
}

\author{
V. E. Brando ${ }^{1,2}$, F. Braga ${ }^{3}$, L. Zaggia ${ }^{3}$, C. Giardino ${ }^{1}$, M. Bresciani ${ }^{1}$, E. Matta ${ }^{1}$, D. Bellafiore ${ }^{3}$, C. Ferrarin ${ }^{3}$, F. Maicu ${ }^{3}$,

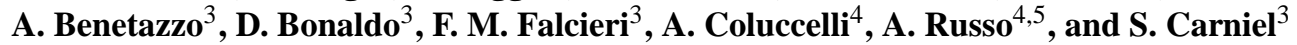 \\ ${ }^{1}$ Consiglio Nazionale delle Ricerche - Istituto per il Rilevamento Elettromagnetico Ambientale (CNR-IREA), \\ Via Bassini 13, 20133 Milan, Italy \\ ${ }^{2}$ Commonwealth Scientific \& Industrial Research Organization (CSIRO), Canberra, Australia \\ ${ }^{3}$ Consiglio Nazionale delle Ricerche - Istituto di Scienze Marine (CNR-ISMAR), Arsenale-Tesa 104, \\ Castello 2737/F, 30122 Venice, Italy \\ ${ }^{4}$ Università Politecnica delle Marche - Dipartimento di Scienze della Vita e dell'Ambiente (UNIVPM-DISVA), \\ Via Brecce Bianche, 60131 Ancona, Italy \\ ${ }^{5}$ NATO STO Centre for Maritime Research and Technology, V.le San Bartolomeo 400, 19126 La Spezia, Italy
}

Correspondence to: V. E. Brando (brando.v@irea.cnr.it)

Received: 30 June 2015 - Published in Ocean Sci. Discuss.: 4 August 2015

Revised: 3 November 2015 - Accepted: 5 November 2015 - Published: 23 November 2015

\begin{abstract}
Sea surface temperature (SST) and turbidity (T) derived from Landsat 8 (L8) imagery were used to characterize river plumes in the northern Adriatic Sea (NAS) during a significant flood event in November 2014. Circulation patterns and sea surface salinity (SSS) from an operational coupled ocean-wave model supported the interpretation of the plumes' interaction with the receiving waters and among them.

There was a good agreement of the SSS, T, and SST fields at the sub-mesoscale and mesoscale delineation of the major river plumes. L8 $30 \mathrm{~m}$ resolution also enabled the description of smaller plume structures. The different plumes' reflectance spectra were related to the lithological fingerprint of the sediments in the river catchments.

Sharp fronts in $\mathrm{T}$ and SST delimited each single river plume. The isotherms and turbidity isolines' coupling varied among the plumes due to differences in particle loads and surface temperatures in the discharged waters. The surface expressions of all the river plumes occurring in NAS were classified based on the occurrence of the plume dynamical regions in the $\mathrm{L} 830 \mathrm{~m}$ resolution imagery.
\end{abstract}

\section{Introduction}

Riverine discharges in the coastal ocean form river plumes, distinct regions where water mass properties are significantly influenced by riverine freshwater as it merges into ocean waters with different thermohaline and dynamical properties (Horner-Devine et al., 2015). The extent, motion, and general structure of river plumes are mainly determined by the advection and mixing processes of freshwater from the river mouth, while the along-coast transport of the riverborne material is determined by several processes, including stratified-shear mixing, frontal processes, oceanic transport, tide and wind forcing, as well as Coriolis effects (Hetland, 2005; Horner-Devine et al., 2015; Geyer et al., 2004; Nof and Pichevin, 2001). The relative importance of these processes determines the overall fate and transport of freshwater, as well as the associated dissolved and particulate matter within the plume (Horner-Devine et al., 2015; Devlin and Schaeffelke, 2009; Brodie et al., 2010; Syvitski et al., 2005).

Following Horner-Devine et al. (2015, and references therein), the river plume structures can be described in terms of four regions characterized by different dominant dynamical balances: (1) the source region, where the buoyancy and momentum that initiate a river plume are determined by es- 
tuarine processes; (2) a jet-like near-field region of initial plume expansion; (3) an unsteady, anticyclonic eddy circulation, i.e. a "bulge", that accumulates a fraction of the river discharge; and (4) a region beyond where the plume water has lost all memory of the inflow momentum but is still distinct from the ambient receiving water, i.e. a far-field plume or coastal current.

Within the Mediterranean Sea, the northern Adriatic Sea (NAS, Fig. 1) is the sub-basin most influenced by river plumes (Degobbis et al., 2000; Spillman et al., 2007; Falcieri et al., 2014). The NAS is a shallow (average depth is smaller than $35 \mathrm{~m}$ ) and semi-enclosed regional sea, which due to the high amount of freshwater is generally considered a dilution basin (Degobbis et al., 2000; Spillman et al., 2007). Riverine input along the northern Adriatic coast is generally associated with sharp coastal fronts and significantly contributes in driving a southeastward current along the Italian coast (Bergamasco et al., 1999), while mechanisms and sub-mesoscale patterns of plume spreading within the basin are strongly controlled by the modulation of freshwater discharge and wind regime (Bignami et al., 2007; Falcieri et al., 2014; Spillman et al., 2007; Tesi et al., 2011). Sediment dispersal in the basin is mostly controlled by the wave action generated by dominant and prevailing winds blowing on the Adriatic Sea, namely, Bora and Sirocco (see e.g. Sclavo et al., 2013; Boldrin et al., 2009).

During flood events the Po, Adige, and Brenta rivers produce an almost single river plume, contributing $84 \%$ of the total freshwater discharge delivered to the basin (Cozzi and Giani, 2011; Falcieri et al., 2014). However, the local effects of the northern rivers (from Isonzo to Piave rivers, Fig. 1) is considerable, since they can contribute with lowsalinity patches that are relevant to mesoscale and submesoscale dynamics (Marini et al., 2008; Solidoro et al., 2009). These freshwater discharges and associated particulate and dissolved matter inputs have a significant effect, both on the physical and biogeochemical properties of the whole basin (Zavatarelli et al., 1998; Marini et al., 2008; Solidoro et al., 2009; Bignami et al., 2007; Barale et al., 1986; Tesi et al., 2011).

Following a large regional precipitation event which affected northern Italy in November 2014, all NAS rivers flooded concurrently (Fig. 2). Peak discharge for the Po River reached $8375 \mathrm{~m}^{3} \mathrm{~s}^{-1}$ on 19 November 2014, the fifth highest of the last 100 years (Montanari, 2012). The timing of the flood for each river varied reflecting the space-time distribution of precipitation and catchment morphology: Piave, Brenta, and Isonzo peaked earlier on 6-7 November, Livenza and Adige on 8 November, while Po peaked for the first time on 9 November $\left(\sim 4000 \mathrm{~m}^{3} \mathrm{~s}^{-1}\right)$ and then reached the maximum discharge on 19 November. During this combined flood event a total of $\sim 15 \mathrm{~km}^{3}$ of freshwater entered NAS, of which $\sim 10 \mathrm{~km}^{3}$ entered the basin by 19 November 2014 , equating to $\sim 1 \%$ of the basin volume.

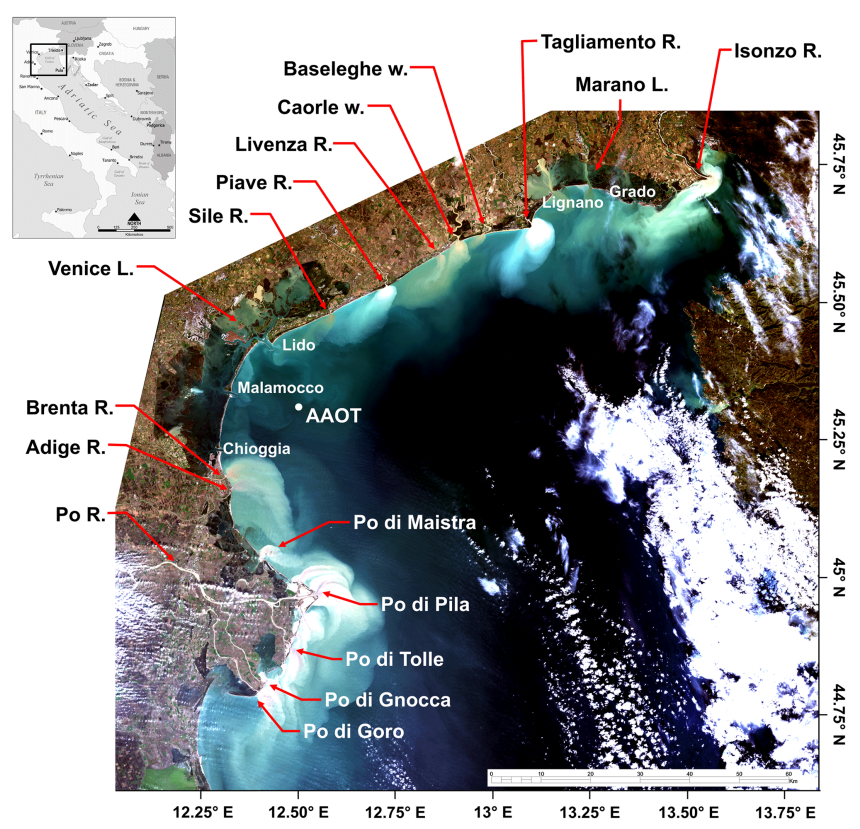

Figure 1. Study site with the location of rivers (R.), lagoons (L.), and wetlands (w.). Pseudo-true-colour Landsat 8 OLI imagery acquired on 19 November 2014. AAOT is the Acqua Alta Oceanographic Tower.

Earth observation has been widely used to describe mesoscale dynamics and physical oceanographic characteristics of river plumes fronts using sea surface temperature (SST) and ocean colour radiometry (OCR) sensors (e.g. Ullman and Cornillon, 1999; D'Sa et al., 2007; Palacios et al., 2009; Schroeder et al., 2012; Brodie et al., 2010). Several studies have combined SST with OCR data and/or with model data to quantify the extent, strength, and variability of the river plumes fronts and to explain their behaviour in relation to the main physical forcing processes (e.g. Hickey et al., 2005; Otero et al., 2009; Pietrzak et al., 2011; Falcini et al., 2012; Margvelashvili et al., 2013; Bignami et al., 2007). Most of these studies were based on data acquired from MODIS, SeaWiFS or AVHRR sensors with a $1-4 \mathrm{~km}$ spatial resolution and 1-3 days' revisit time (Robinson, 2010).

Historically, Landsat data have been used in coastal and inland waters to map both particulate matter and surface temperature at finer spatial resolution $\quad(\sim 30$ and $\sim 100 \mathrm{~m}$ respectively) (Hellweger et al., 2004; Fisher and Mustard, 2004, and references therein). The recently launched Landsat 8 (L8) has been deemed suitable for studying aquatic environments due to improved data quality and spectral coverage (Irons et al., 2012; Pahlevan et al., 2014).

In this study we combined SST and turbidity (T) derived from L8 imagery to describe river plumes and their sub-mesoscale interactions in the NAS during the significant combined flood event of November 2014 at fine spatial resolution. To this aim we used the model data from an operational coupled ocean-wave modelling system to sup- 


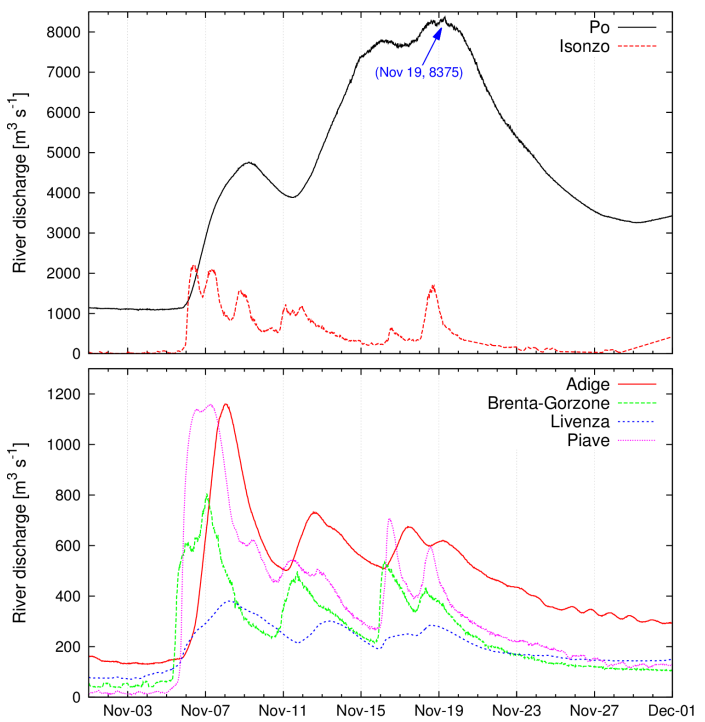

Figure 2. River discharge for November 2014 for the main rivers flowing in NAS.

port the interpretation of the plumes' dynamics and their interaction with the receiving waters and among them. Section 2 provides details on the satellite imagery processing and on the operational coupled ocean-wave modelling system, while in Sect. 3 the optical and spatial characterization of the river plumes based on $\mathrm{T}$ and the SST fields is presented. In this work we classified the surface expressions of all the river plumes occurring in NAS based on L8 $30 \mathrm{~m}$ resolution imagery following the Horner-Devine et al. (2015) classification scheme for plume morphology, thus extending the broad classification carried out by Syvitski et al. (2005) using MODIS imagery at $250 \mathrm{~m}$ resolution.

\section{Methods}

\subsection{Satellite imagery}

To image the Earth throughout the visible and thermal portions of the spectrum, L8 carries two separate sensors, the Operational Land Imager (OLI) and the Thermal Infrared Radiometer Sensor (TIRS). Both OLI and TIRS represent an evolution in Landsat sensor technology in terms of data quality and spectral coverage (Irons et al., 2012). The OLI provides coverage of the visible, near-infrared, and short-wave infrared (SWIR) portions of the spectrum at $30 \mathrm{~m}$ spatial resolution in nine spectral bands with a relatively high signal to noise ratio ( $\sim 300$ for the blue bands) (Irons et al., 2012; Pahlevan et al., 2014). OLI data are considered particularly adequate for ocean colour retrievals and turbidity mapping due to the radiometric resolution and calibration accuracy (Pahlevan et al., 2014; Vanhellemont and Ruddick, 2014; Franz et al., 2015). The TIRS adds two long-wave thermal spectral bands at $100 \mathrm{~m}$ spatial resolution, centred at 10.9 and $12.0 \mu \mathrm{m}$ (bands 10 and 11, respectively) (Irons et al., 2012). As these two Landsat 8 data sets are complementary, they are distributed as combined data products, where the TIRS $100 \mathrm{~m}$ pixels are resampled and co-aligned with the OLI $30 \mathrm{~m}$ data (Irons et al., 2012; Storey et al., 2014).

In this study we used OLI and TIRS imagery of 19 November 2014, capturing a significant freshwater inflow into the NAS for mapping both T and SST. For turbidity, OLI data were converted into water-leaving radiance reflectance $\left(\rho_{\mathrm{w}}\right.$, dimensionless) with ACOLITE (Atmospheric Correction for OLI "lite"), an automatic method for atmospheric correction designed specifically for OLI over turbid waters (Vanhellemont and Ruddick, 2014, 2015). As recommended in moderately to extremely turbid waters (Vanhellemont and Ruddick, 2015), a per-pixel variable aerosol type was determined from the ratio of reflectances in the SWIR bands (1609, $2201 \mathrm{~nm}$ ), after having applied the Pahlevan et al. (2014) radiance gains for radiometric calibration. The $\rho_{\mathrm{w}}$ data were then converted into $\mathrm{T}$ expressed in formazin nephelometric unit (FNU), following Dogliotti et al. (2015). At higher T values, $\rho_{\mathrm{w}}(655 \mathrm{~nm})$ starts to saturate while $\rho_{\mathrm{w}}(865 \mathrm{~nm})$ still linearly increases with T. Hence, they use a switching scheme to avoid saturation at $655 \mathrm{~nm}$ and retrieve T accurately in the 11500 FNU range (within $\sim 13 \%$ of in situ data, Dogliotti et al., 2015). SST values were retrieved from top-of-atmosphere brightness temperature in the TIRS band $10(10.9 \mu \mathrm{m})$ with a radiative-transfer-based atmospheric correction (Barsi et al., 2005, 2014).

\subsection{Hydrodynamic forecasting model}

As a complement to the L8 images, we analysed model data generated by an operational implementation in the northern Adriatic basin of the Coupled Ocean-AtmosphereWave-Sediment Transport (COAWST, Warner et al., 2008), where the Regional Ocean Modeling System (ROMS) and the Simulating Wave Nearshore (SWAN) model are twoway fully coupled (Russo et al., 2013a, b). COAWST was implemented for the NAS on a grid with horizontal spacing of $0.5 \mathrm{~km}$ and 12 vertical terrain-following sigma levels, offline-nested to parent operational models covering the whole Adriatic and the Italian seas (Russo et al., 2013a, b). The operational systems were forced by the operational highresolution $(7 \mathrm{~km} \times 7 \mathrm{~km})$ meteorological model COSMO-I7 (Russo et al., 2013a, b). Following Hetland (2005), at the river mouths' grid cells, momentum was injected, giving a vertical structure to the plume, i.e. injecting most of the freshwater discharge in the surface layers $(\sim 80 \%$ in the four uppermost sigma levels, corresponding to about $1.5 \mathrm{~m}$ ). Daily time series of freshwater supplies from the Po River were imposed (and kept constant along the $72 \mathrm{~h}$ of forecast), while the remaining NAS rivers were prescribed based on monthly climatological estimates (Raicich, 1994). To represent the Po River delta system, the flow measured at Ponte- 
lagoscuro ( $90 \mathrm{~km}$ upstream the river mouth) is split into five major branches (Maistra, Pila, Tolle, Gnocca, and Goro), following the partitioning proposed in Zasso and Settin (2012). Minor Po River branches, north of the Po di Pila mouth, and some minor freshwater inputs (e.g. nearby the Caorle and Baseleghe wetlands) are not considered.

To delineate the surface extent of river plumes and the freshwater influence in the basin, the daily averaged surface level of the modelled salinity field was considered as the sea surface salinity (SSS) field. This approach explicitly does not consider the vertical structure of the plume or the mixed layer depth (as proposed in Otero et al., 2008, 2009), as the shallow waters of NAS and the weak tidal dynamics do not always allow the development or the identification of a mixed layer (Falcieri et al., 2014). Hence, following Falcieri et al. (2014), in this study the surface extent of the freshwater influence in the NAS was identified with the 36 isohaline resulting from the salinity fields obtained by the numerical model.

\section{Results and discussion}

In the pseudo-true-colour composite of the OLI imagery of 19 November 2014 (Fig. 1) two very large regions of freshwater influence (ROFI; sensu Simpson, 1997) are delineated in the NAS by the convolution of the plumes generated by the northern rivers from the Isonzo to the Piave and then by the western rivers i.e. the Brenta, Adige, and Po. As the river mouths are close to each other, sharp fronts delineate the river plumes from the cyclonic coastal current, transporting dissolved and particulate matter from upstream plumes. The area in front of the Venice Lagoon shows specific patterns generated by the interaction between the coastal current and local tidal dynamics at the lagoon inlets, enhanced by the presence of long artificial jetties (Bellafiore and Umgiesser, 2010).

\subsection{Meteo-oceanographic conditions}

The basin was characterized by relatively calm conditions in the days before the L8 image retrieval. Modelled regional circulation patterns in the week from 12 to 19 November 2014 were initially dominated by a southeastward current along the Italian coast (daily average speed up to $0.7 \mathrm{~m} \mathrm{~s}^{-1}$ at the sea surface), although the freshwater injected in the previous days (6-11 November 2014, see Fig. 2) had already spread over a large fraction of NAS (Fig. 3a). The increasing riverine inflow progressively enhanced the effect of Po River in controlling surface circulation in the NAS, with a plume spreading offshore with strong vertical gradients in temperature and salinity (Fig. 3b). These patterns are consistent with the conditions recorded at the Acqua Alta Oceanographic Tower (AAOT) located about $15 \mathrm{~km}$ off the Venice Lagoon (Fig. 1), where on 19 November 2014 the average wind speed was $4 \mathrm{~m} \mathrm{~s}^{-1}$ and the sea state was characterized by a mean significant wave height smaller than $0.3 \mathrm{~m}$. Depthaveraged oceanic currents were weak (reaching a modelled value of $0.1 \mathrm{~m} \mathrm{~s}^{-1}$ ) and mostly directed southwestwardly, while surface currents appeared to be dominated by riverine inflow. In particular, modelled surface current velocities exceeded $0.5 \mathrm{~m} \mathrm{~s}^{-1}$ in large coastal areas off the Po River mouths, while the propagation of the plume (isohaline 36) was characterized by velocities of approximately $0.35 \mathrm{~m} \mathrm{~s}^{-1}$ in large sectors of the frontal region (Fig. 3b).

\subsection{Spectral properties}

From a qualitative point of view, the plumes and the coastal waters in the NAS appear very different in colour, ranging from white to yellow/brown shades in the pseudo-true-colour composite (Fig. 1). Figure 4 presents reflectance spectra extracted from selected locations of interest in NAS: the spectra for the centre of the basin (indicated as "open waters" in Fig. 4a) have a peak at 443 and $482 \mathrm{~nm}$, typical of blue waters ( $\rho_{\mathrm{w}}$ (482) ranging 0.01-0.03), while the AAOT, the Venice Lagoon inlets (Chioggia, Malamocco, and Lido), and the Grado inlet of the Marano Lagoon have a $562 \mathrm{~nm}$ peak, typical of green waters $\left(\rho_{\mathrm{w}}(562)\right.$ ranging $\left.0.04-0.07\right)$. The waters flowing from the western Marano Lagoon (Lignano inlet) and Caorle and Baseleghe wetlands have higher spectra, and $\rho_{\mathrm{w}}$ values at 562 and $655 \mathrm{~nm}$ are very similar (ranging $0.10-0.12$ and $0.08-0.12$, respectively).

The river plumes spectra show a peak at $655 \mathrm{~nm}$ of whitish/yellow/brown waters $\left(\rho_{\mathrm{w}}(655)\right.$ ranging $0.09-0.23$, Fig. 4b). In particular, the Isonzo, Tagliamento, and Piave river plumes appear as almost white in the pseudo-true colour composite (Fig. 1) as they have high $\rho_{\mathrm{w}}$ at both 562 and $655 \mathrm{~nm}$, while the Po, Brenta, Adige, Sile, and Livenza river plumes appear in yellow/brown shades, as $\rho_{\mathrm{w}}$ (562) is lower, ranging $0.08-0.12$. The Po River plumes show $\rho_{\mathrm{W}}$ (865) ranging $0.10-0.12$, similar to values found for $\rho_{\mathrm{w}}$ (655), whilst for all other river plume spectra, $\rho_{\mathrm{w}}$ (865) was lower than the $\rho_{\mathrm{w}}(655)$.

The very high reflectances and the colours of eastern Alpine river plumes (Isonzo, Tagliamento, and Piave) are related to carbonate-rich sediments, yielded by their prevailing Mesozoic limestone and dolomite catchments (Pigorini, 1968; Castellarin and Vai, 1982). The yellow/brown shades of all the other rivers are due to the lithological fingerprint of their sediments. The Brenta River drains a mix of carbonate, volcanic, and metamorphic terrains in the northeastern Alps (Dinelli and Lucchini, 1999). The Adige River drains a metamorphic and porphyric catchment in the northeastern Alps (Dinelli and Lucchini, 1999). The Po River drains both the Alps and Northern Apennines, respectively characterized by metamorphic-intrusive rocks and a terrigenous sequence (shales, calcareous, mudstone, and sandstone) (Dinelli and Lucchini, 1999). Some of the major rivers (e.g. Brenta and Po) also drain mixed river deposits of the floodplain and agricultural soil, while the remaining minor rivers, including trib- 


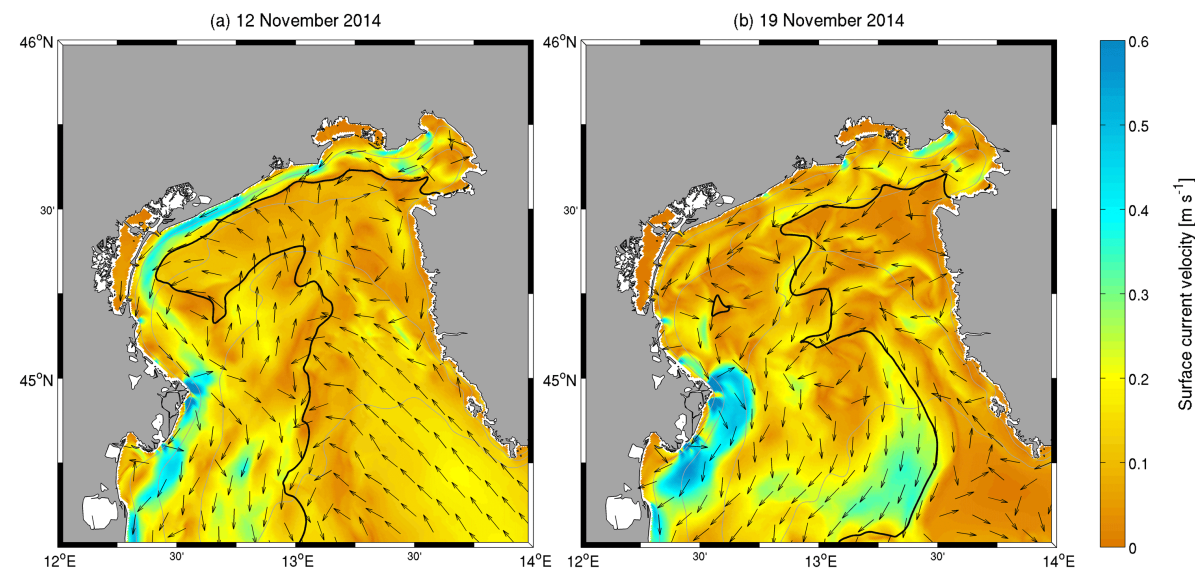

Figure 3. Daily-averaged modelled surface currents velocities in the NAS on 12 November 2014 (a) and 19 November 2014 (b). Normalized vectors indicating current direction have been subsampled every 15 grid points for graphical purposes; the black thick line indicates modelled isohaline 36 .
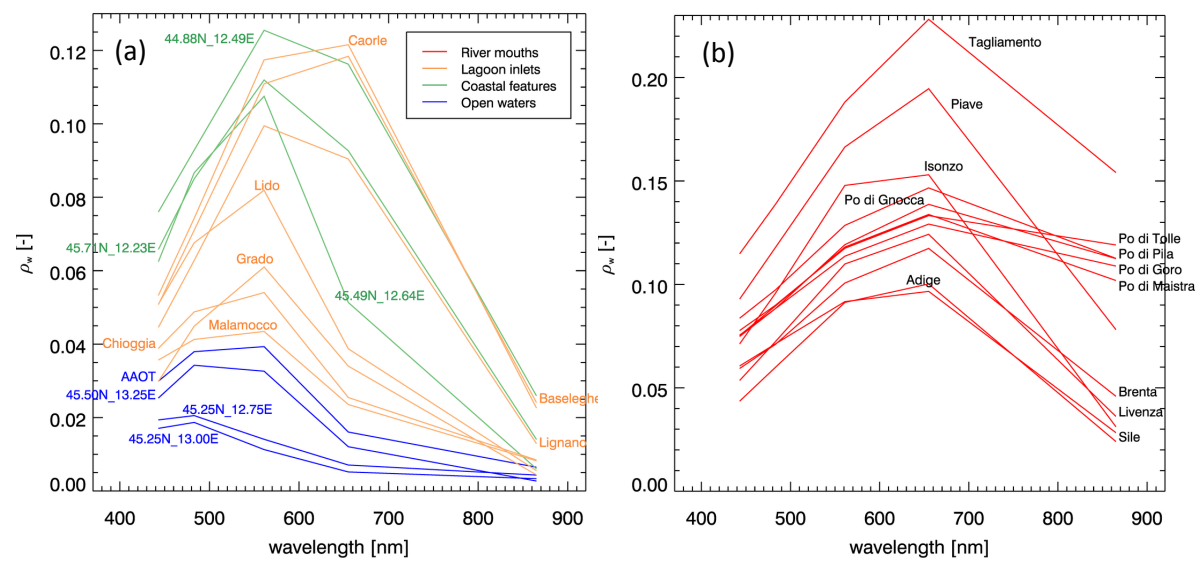

Figure 4. Reflectance spectra extracted from selected locations in NAS, including open waters, coastal features, lagoon inlets (a), and river mouths (b).

utaries from Venice and Marano lagoons, mostly drain these reworked terrains (Piovan et al., 2010). A considerable fraction of the flux from wetland-lagoon systems, constituted of organic particulate and high dissolved matter, also contribute to the dark-brown colour.

\subsection{SST and SSS fields}

Following Falcieri et al. (2014), we can identify the surface extent of the freshwater influence in the NAS with the 36 isohaline resulting from the salinity fields obtained by the numerical model (Fig. 5). The freshwater discharged during the combined flood event extended $12-15 \mathrm{~km}$ offshore for the plumes generated by the northern rivers, $\sim 50 \mathrm{~km}$ in front of the Adige and Brenta rivers and more than $60 \mathrm{~km}$ in front of the Po River, consistently with the Falcieri et al. (2014) highdischarge plume patterns. For the northern rivers and the Po River the 35 and 36 isolines were within $2-3 \mathrm{~km}$, whilst for the area in front of the Venice Lagoon and the Adige and Brenta rivers, these isohalines were $20-40 \mathrm{~km}$ apart.

Overall, the waters delineated by the 36 isohaline were colder $\left(\sim 12-17^{\circ} \mathrm{C}\right)$ than the adjacent ocean waters $\left(\mathrm{SST}>\sim 18^{\circ} \mathrm{C}\right)$. In particular, SST ranged between 12 and $15^{\circ} \mathrm{C}$ for the river and lagoon plumes, and between 15 and $17^{\circ} \mathrm{C}$ in the coastal current connecting the river plumes. The area in front of the Venice Lagoon was warmer than the neighbouring ROFIs (SST $=16-18^{\circ} \mathrm{C}$ ). The SST field was consistent with the autumn/winter flood conditions described in previous studies on the SST dynamics in NAS (Gacic et al., 1997; Barale et al., 2004; Borzelli, 2008; Bignami et al., 2007).

The over-imposed isohalines showed a good correspondence with the observed SST field in delineating the major river plumes (Isonzo Tagliamento, Brenta, Adige, and Po rivers) at the mesoscale. For the northern rivers between the Isonzo and the Piave, the 36 isohaline coincided with $17.5^{\circ} \mathrm{C}$ 


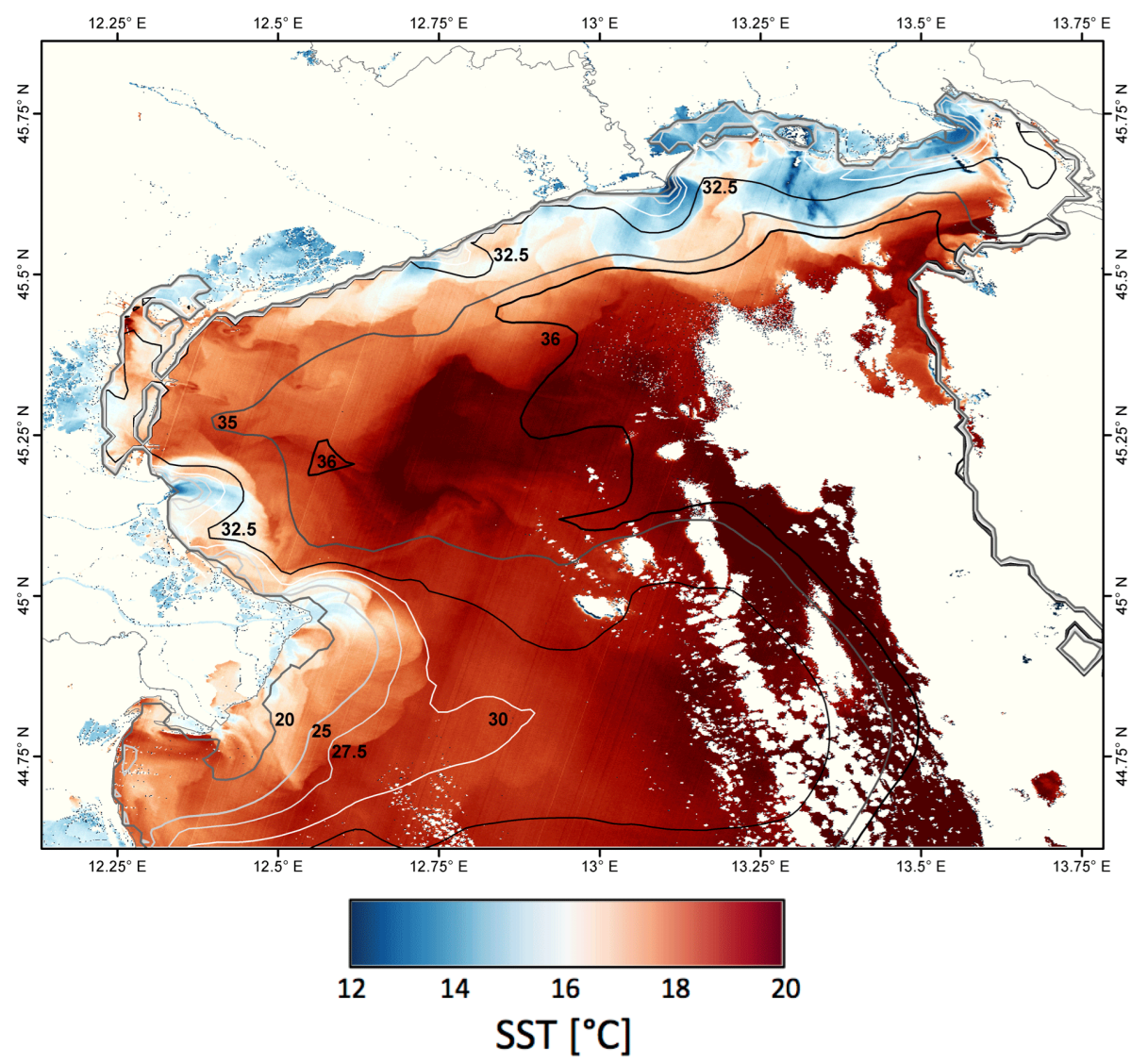

Figure 5. SST field estimated from Landsat 8 TIRS imagery acquired on 19 November 2014. Isohalines from the modelled SSS field are overlaid.

isotherm, while in front of the Brenta, Adige, and Po rivers, the 36 isohaline coincided with the $19.5^{\circ} \mathrm{C}$ isotherm. Due to the lack of near real-time data for freshwater discharge for all rivers except the Po, and as some minor freshwater inputs (e.g. the Caorle and Baseleghe wetlands) are not considered in the model, there were some areas of mismatch between the SST and SSS fields at the submesoscale, particularly in the coastal region east of the Venice Lagoon.

As the L8 TIRS $100 \mathrm{~m}$ pixels are resampled and co-aligned with the OLI $30 \mathrm{~m}$ data, the SST data used in this study have a spatial resolution 1 or 2 orders of magnitude finer than the satellite data used for previous SST studies (Gacic et al., 1997; Barale et al., 2004; Borzelli, 2008; Bignami et al., 2007). Therefore, in the L8 SST field, it is possible to identify small near-shore trapped warm water (NTWW) parcels, which are warmer than the adjacent plumes and the coastal current, with values similar to those of the central part of the basin (SST ranging $17-19^{\circ} \mathrm{C}$ ). These NTWWs are located outside of the Marano Lagoon $\left(45.71^{\circ} \mathrm{N}, 13.23^{\circ} \mathrm{E}\right)$, between the Sile and Piave river plumes $\left(45.49^{\circ} \mathrm{N}, 12.64^{\circ} \mathrm{E}\right)$ and to the south of the Po di Pila $\left(44.88^{\circ} \mathrm{N}, 12.49^{\circ} \mathrm{E}\right)$. These features were also spectrally different than the neighbouring waters, showing a peak typical of green waters with $\rho_{\mathrm{w}}(562)$ ranging 0.09-0.12 (Fig. 4). The occurrence and locations of these small features were not adequately captured by the model-derived SSS, most likely due to resolution limits.

\subsection{Turbidity field}

Figure 6 presents the maps of $\mathrm{T}$ for the northern rivers (Fig. 6a) and the Brenta, Adige, and Po river plumes (Fig. 6b). Close to the river mouths, the Tagliamento River plume presented the most turbid waters $(\mathrm{T}>1700 \mathrm{FNU})$, while $\mathrm{T}$ ranged $600-800 \mathrm{FNU}$ for the Po River plumes and 100-300 FNU for the other rivers. In the cyclonic coastal gyre connecting the plumes, $\mathrm{T}$ ranged 10-30 FNU, while for the open waters outside the ROFIs it ranged 1-5 FNU. The NTWWs were also clearly identifiable in the T field: $\mathrm{T}$ ranged $10-50 \mathrm{FNU}$, up to 1 order of magnitude lower than the neighbouring plumes and significantly higher than the open ocean waters.

As the wind and wave re-suspension was negligible during this event, $\mathrm{T}$ is mostly related to the suspended particle load transported by the plumes in the basin (Sclavo et al., 2013; Tesi et al., 2011; Boldrin et al., 2009). Since T higher than $\sim 3-5$ FNU can be deemed as indicative of terrestrial discharge in NAS (Boldrin et al., 2005, 2009; Tesi et al., 2011; 

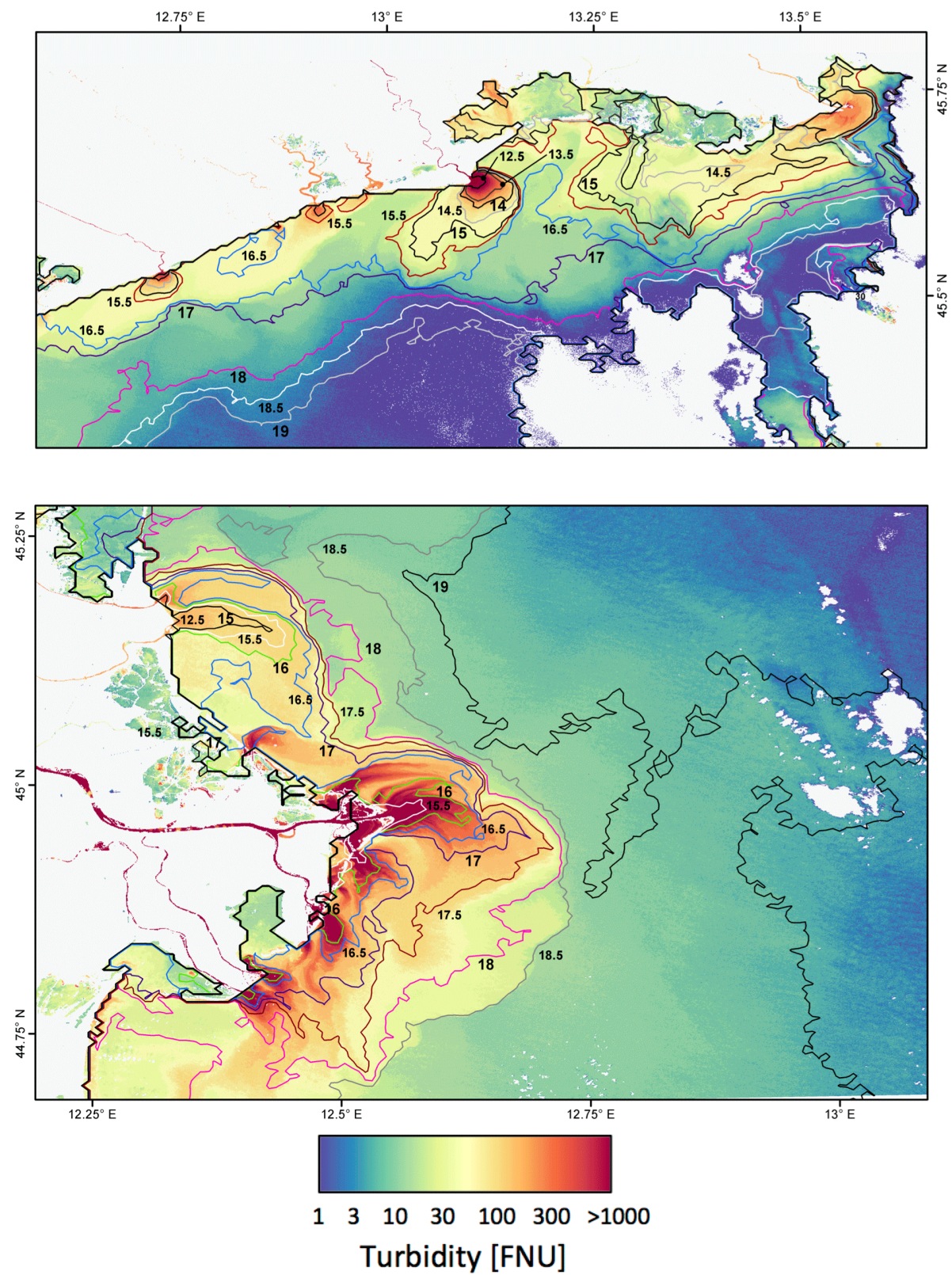

Figure 6. Turbidity map estimated from Landsat 8 OLI imagery acquired on 19 November 2014: (a) all the plumes from the Isonzo to the Piave River, (b) the Brenta, Adige, and Po river plumes. Isotherms from the Landsat 8 TIRS SST field are overlaid. To enhance readability, some isotherms have different colour coding in the two areas.

Braga et al., 2013), these values were used to delineate the surface expression of the plumes in the T field from the adjacent ocean waters (Fig. 6). Based on the 3 and 5 FNU isolines, in this event the combined plumes of suspended matter delivered by northern rivers extended $15-18 \mathrm{~km}$ offshore, the plumes of Adige and Brenta rivers spread $20-28 \mathrm{~km}$ from the coast, while the Po River plume reached a distance of $30-50 \mathrm{~km}$.

At the submesoscale, the L8-derived T field (Fig. 6) is coherent with the overall pattern of suspended matter de- scribed in previous studies based on satellite data and conducted during autumn/winter floods, although their investigations were performed using different satellite-derived products. For instance, Barale et al. (1984) presented the vertical attenuation coefficient variability, Bignami et al. (2007) used both the vertical attenuation coefficient and an index for turbid (Case 2) waters' occurrence, while other studies (Barale et al., 1986, 2005; Böhm et al., 2003; Spillman et al., 2007) used OCR-derived chlorophyll concentration as a proxy to 
describe the basin response to freshwater discharge and wind events.

\subsection{Dilution pathways}

Following Horner-Devine et al. (2015, and references therein), the river plume structures can be described in terms of four dynamical regions characterized by different dominant dynamical balances: (1) the source region; (2) the jetlike near-field region; (3) the "bulge" that accumulates a fraction of the river discharge; and (4) the far-field plume or coastal current. The pathway to dilution for terrestrially derived freshwater is defined by the mixing and transport processes occurring in the plumes, as the discharge salinity increases through the plume dynamical regions before its ultimate dissolution into the adjacent ocean waters (HornerDevine et al., 2015). The sharp fronts delimiting each single river plume observed in Figs. 1, 5, and 6 appear delineated both by $\mathrm{T}$ and SST even if the isotherms and turbidity isolines' coupling varied among the plumes due to differences in particle loads and surface temperatures in the discharged waters (Fig. 7).

Close to the river mouths (SSS <20), the Tagliamento and Po river plumes differed both in $\mathrm{T}$ and $\mathrm{SST}\left(\sim 12.5^{\circ} \mathrm{C}\right.$, $\sim 1700 \mathrm{FNU}$ and $\sim 15.5^{\circ} \mathrm{C}, 600-800 \mathrm{FNU}$ respectively, Fig. 7). The dilution of the terrestrial discharge for the Po and Tagliamento rivers towards "clear" ocean waters (i.e. $\mathrm{T}<3 \mathrm{FNU}, \mathrm{SSS}>36$ ) consistently maintained a $\sim 2.5^{\circ} \mathrm{C}$ difference. Moreover, the $\mathrm{T}$ and SST coupling at the river mouth (i.e. in the near-field region) does not necessarily reflect the composition of the transported particulate matter, as the Adige and Isonzo rivers $\left(\sim 13^{\circ} \mathrm{C}, \sim 100 \mathrm{FNU}\right)$ or the Livenza and Brenta rivers $\left(\sim 14.5^{\circ} \mathrm{C}, \sim 150 \mathrm{FNU}\right)$ have similar coupling but transport different material sources as described in Sect. 3.3.

The offshore borders of the far-field plume connecting the individual plumes - identified by the 35 and 36 isohaline - corresponded to different turbidity isolines and isotherms (Figs. 5, 6 and 7). For the northern rivers, the 36 isohaline corresponded to the $3 \mathrm{FNU}$ isoline and the $17.5^{\circ} \mathrm{C}$ isotherm. For the western far-field plume, the 36 isohaline was at $\sim 60 \mathrm{~km}$ offshore and corresponded to the $19.5^{\circ} \mathrm{C}$ isotherm and the $1-2 \mathrm{FNU}$ isolines, while the $3 \mathrm{FNU}$ isoline was $15 \mathrm{~km}$ closer to the river mouth. This pattern may be a consequence of freshwater dilution and particles settling in the frontal region.

\subsection{Plume morphologies}

Based on the presence/absence of the four dynamical regions, Horner-Devine et al. (2015) proposed a classification of six plumes' morphologies (plumes A-F). The surface expressions of these morphologies can be identified in Figs. 1, 5, and 6 for the NAS plumes observed on 19 November 2014:
- The Isonzo, Tagliamento, Piave, Adige, and Brenta rivers form "prototypical" plumes (plume A), comprising all dynamical regions: the initial jet-like plume expansion forms a bulge that then merges in the coastal current.

- The Livenza River jet-like plume merges in the coastal current without forming an anticyclonic eddy, probably because of the very long jetties; hence it may be classified as a non-rotational plume (plume B).

- The freshwater discharged in the western side of the Marano Lagoon forms a wide estuary plumes type (plume $\mathrm{C}$ ) on the ocean side. In this case the tidal dynamics lead to a not well-defined near-field, a weak mid-field, and no bulge.

- The discharge from the Baseleghe wetland forms an "angled inflow" plume (plume D), showing no bulge, due to a significant component of alongshore momentum as the inflow is at a small angle to the coast.

- The Po River enters the NAS through a deltaic system, delivering freshwater via five main river channels. The Po River delta plume is thus the "convolution" of multiple plumes formed by each of the 12 channel outlets interacting with each other (plume E). Plume dynamics for each single plume depend on the river flow thrust in the branch and on behaviour of neighbouring plumes. The plumes at the mouth of the various branches have similar concentrations of particulate matter $(\mathrm{T}=600-$ 800 FNU, Figs. 6 and 7), even if they differ in proportion of freshwater discharge and ability to transport sediment away from the coast.

- The shallow characteristics of the whole NAS littoral zone allow the identification of wider coastal areas where several rivers contribute to a common hydrological and hydrodynamic pattern. The interactions of the northern rivers' plumes from the Isonzo to the Piave River, and then of the western rivers - the Brenta, Adige, and Po river plumes - form two distinct ROFIs (plume F) where the plume water has lost memory of the inflow momentum but is still distinct from the ambient receiving water. The offshore borders of these ROFIs corresponded to different turbidity isolines and isotherms: the 36 isohaline corresponded to the $3 \mathrm{FNU}$ isoline and the $17.5^{\circ} \mathrm{C}$ isotherm for the northern ROFI, and to the $19.5^{\circ} \mathrm{C}$ isotherm and 1-2 FNUs for the western ROFI.

- The Venice Lagoon, as a specific transitional water body with scarce freshwater sources in its interiors, could not properly be classified as a ROFI. Coastal circulation in front of the lagoon is dominated by tidal dynamics, and the presence of jetties and breakwaters at the inlets highly influences the shaping of less salty water (but still 


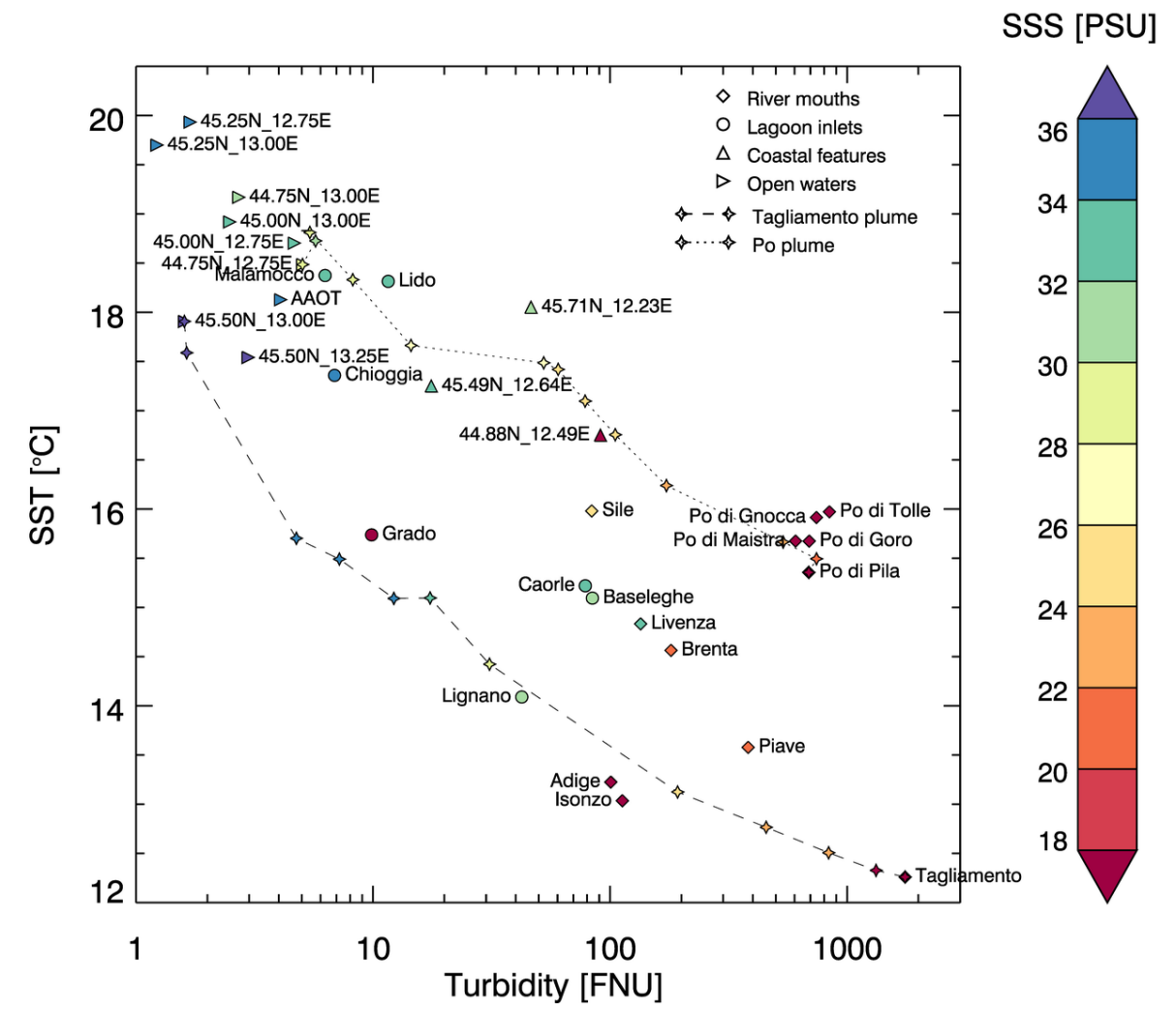

Figure 7. Relations between turbidity, SST, and SSS for selected locations in NAS. The dilution of the Po and Tagliamento river plumes across the SSS gradient is shown with dashed lines.

not freshwater) tidal plumes (Bellafiore and Umgiesser, 2010).

The classification of the surface expressions of all the river plumes occurring in NAS based on L8 $30 \mathrm{~m}$ resolution imagery extends the broad classification carried out by Syvitski et al. (2005) for the flood of the combined NAS rivers in December 2000, using MODIS imagery at $250 \mathrm{~m}$ resolution, where the northern rivers generated "jet-like plumes", while the Po River delta produced a "more diffusive plume".

\section{Conclusions}

In this study, the combined use of high-resolution OCR and SST imagery enabled the identification of the dynamical regions at the small scale and submesoscale for all plume structures and their interactions in the NAS. The independent satellite observations of T and SST were used as tracers for the surface expression of the freshwater influence in this significant flood event. This was corroborated by the good agreement of the patterns in these fields with the modelled SSS field at the submesoscale and mesoscale. Furthermore, the radiometric and spatial resolution of the L8 OLI and TIRS imagery enabled the classification of the NAS plumes of 19 November 2014 based on their morphology including the description of smaller plume structures and the NTWWs, whilst these features were not adequately resolved by the $500 \mathrm{~m}$ resolution of the SSS model data. To our knowledge, this study provided the first evidence of NTWWs in NAS.

Although the event discussed in this study was captured with a sensor with a revisiting time of 16 days, we expect that with the recent launch of ESA's Sentinel-2A and the forthcoming launch of Sentinel-2B, the temporal resolution will increase, almost reaching those normally associated with OCR missions (Dickey, 2003; Hestir et al., 2015; Mouw et al., 2015). Combined with their radiometric resolution similar to OCR missions, these developments will thus offer an opportunity to also describe the temporal evolution of plume structures at the submesoscale.

The observed optical complexity of NAS due to the variability in composition of the particulate matter may affect accuracy of the Dogliotti et al. (2015) algorithm for T retrievals, and the relationship between $\mathrm{T}$ and suspended matter concentration for each river. Hence, future work is needed to characterize the inherent and apparent optical properties of particulate and dissolved matter delivered by each river in flood and non-flood conditions. This will also enable the validation of the Dogliotti et al. (2015) algorithm and the parameterization of other OCR algorithms (e.g. Melin et al., 2011; Vantrepotte et al., 2012; Brando et al., 2012) to accurately 
retrieve chlorophyll and suspended matter concentrations in these complex coastal waters.

There are almost no studies on the partitioning of water and sediment fluxes through distributary branches of a delta or adjacent rivers due to the complexity and cost associated with a simultaneous sampling effort at all branches or rivers (Syvitski et al., 2005). Moreover, flood events are difficult to observe in situ; as with ship-based activities, it is seldom possible to reach river mouths while autonomous vehicles are not operating in shallow waters or in highdensity gradients (Hetland, 2005; Devlin and Schaeffelke, 2009; Tesi et al., 2011). However, observations from instrumented sites or coastal observatories such as AAOT provide detailed information on a large array of variables but do not provide a sufficient spatial coverage and may not happen to be located favourably to observe events of interest (Dickey, 2003). Hence, dedicated field and numerical investigations are needed to characterize the temporal evolution of the spatial and vertical structure of the SSS, SST, and T fields of river plumes interacting with the receiving waters and among them, in varying discharge conditions. This would also enable to define the processes leading to the occurrence of NTWWs.

The potential of an integrated use of earth observation, numerical models, and in situ observations for describing coastal dynamics has been progressively emphasized in recent years (e.g. Dickey, 2003; Staneva et al., 2009; Stanev et al., 2011). The adoption of triple-collocation algorithms will allow the intercalibration of quantities and properties retrieved from the different sources (Janssen et al., 2007 and references therein). Furthermore, the use of the independent data sets will enable the identification of the relevant timescales and space scales for the observed (and modelled) phenomena (Chang et al., 2002).

Acknowledgements. Landsat 8 data were downloaded from USGS. Freshwater discharge data were provided by the regional environmental protection agencies: ARPA Veneto, ARPA Emilia Romagna, and Protezione Civile del Friuli Venezia Giulia. Model data for the operational systems (COSMO-I7, AdriaROMS 4.0, and SWAN ITALIA) were provided by ARPA Emilia Romagna.

This study was co-funded by the RITMARE Flagship Project, the European Union (FP7-People Co-funding of Regional, National and International Programmes, GA no. 600407) and the Italian Space Agency (CLAM-PHYM project, contract no. I/015/11/0).

We are grateful to RBINS for making ACOLITE publicly and freely available. Constructive comments by two anonymous reviewers, as well as Erin Hestir, Mark Dowell, Andrea Bergamasco, and Mauro Sclavo improved earlier versions of the manuscript.

Edited by: L. Kantha

\section{References}

Barale, V., Rizzoli, P. M., and Hendershott, M. C.: Remotely Sensing the Surface Dynamics of the Adriatic Sea, Deep-Sea Res., 31, 1433-1459, doi:10.1016/0198-0149(84)90081-5, 1984.

Barale, V., Mcclain, C. R., and Malanotterizzoli, P.: Space and Time Variability of the Surface Color Field in the Northern Adriatic Sea, J. Geophys. Res.-Oceans, 91, 12957-12974, doi:10.1029/Jc091ic11p12957, 1986.

Barale, V., Schiller, C., Villacastin, C., and Tacchi, R.: The Adriatic Sea surface temperature historical record from Advanced Very High Resolution Radiometer data (1981-1999), Int. J. Remote Sens., 25, 1363-1369, 10.1080/01431160310001592300, 2004.

Barale, V., Schiller, C., Tacchi, R., and Marechal, C.: Trends and interactions of physical and bio-geo-chemical features in the Adriatic Sea as derived from satellite observations, Sci. Total Environ., 353, 68-81, doi:10.1016/j.scitotenv.2005.09.060, 2005.

Barsi, J. A., Schott, J. R., Palluconi, F. D., and Hook, S. J.: Validation of a Web-Based Atmospheric Correction Tool for Single Thermal Band Instruments, Earth Observing Systems X, San Diego, CA, Proc. SPIE 5882, 58820E, 7 September 2005, doi:10.1117/12.619990, 2005.

Barsi, J. A., Schott, J. R., Hook, S. J., Raqueno, N. G., Markham, B. L., and Radocinski, R. G.: Landsat-8 Thermal Infrared Sensor (TIRS) Vicarious Radiometric Calibration, Remote Sens., 6, 11607-11626, doi:10.3390/rs61111607, 2014.

Bellafiore, D. and G. Umgiesser: Hydrodynamic coastal processes in the North Adriatic investigated with a 3D finite element mode, Ocean Dynam., 60, 255-273, doi:10.1007/s10236-009-0254-x, 2010.

Bergamasco, A., Oguz, T., and Malanotte-Rizzoli, P.: Modeling dense water mass formation and winter circulation in the northern and central Adriatic Sea, J. Marine Syst., 20, 279-300, doi:10.1016/S0924-7963(98)00087-6, 1999.

Bignami, F., Sciarra, R., Carniel, S., and Santoleri, R.: Variability of Adriatic Sea coastal turbid waters from SeaWiFS imagery, J. Geophys. Res.-Oceans, 112, C03s10, doi:10.1029/2006jc003518, 2007.

Böhm, E., Banzon, V., D’Acunzo, E., D’Ortenzio, F., and Santoleri, R.: Adriatic Sea surface temperature and ocean colour variability during the MFSPP, Ann. Geophys., 21, 137-149, doi:10.5194/angeo-21-137-2003, 2003.

Boldrin, A., Langone, L., Miserocchi, S., Turchetto, M., and Acri, F.: Po River plume on the Adriatic continental shelf: Dispersion and sedimentation of dissolved and suspended matter during different river discharge rates, Mar. Geol., 222, 135-158, doi:10.1016/j.margeo.2005.06.010, 2005.

Boldrin, A., Carniel, S., Giani, M., Marini, M., Aubry, F. B., Campanelli, A., Grilli, F., and Russo, A.: Effects of bora wind on physical and biogeochemical properties of stratified waters in the northern Adriatic, J Geophys Res-Oceans, 114, C08s92, doi:10.1029/2008jc004837, 2009.

Borzelli, G. L. E.: Scales and variability of the sea surface temperature distribution in the Adriatic Sea, J. Geophys. Res.-Oceans, 113, C11s01, doi:10.1029/2007jc004396, 2008.

Braga, F., Giardino, C., Bassani, C., Matta, E., Candiani, G., Strombeck, N., Adamo, M., and Bresciani, M.: Assessing water quality in the northern Adriatic Sea from HICO (TM) data, Remote Sens. Lett., 4, 1028-1037, doi:10.1080/2150704X.2013.830203, 2013. 
Brando, V. E., Dekker, A. G., Park, Y. J., and Schroeder, T.: Adaptive semianalytical inversion of ocean color radiometry in optically complex waters, Appl. Optics, 51, 2808-2833, 2012.

Brodie, J., Schroeder, T., Rohde, K., Faithful, J., Masters, B., Dekker, A., Brando, V., and Maughan, M.: Dispersal of suspended sediments and nutrients in the Great Barrier Reef lagoon during river-discharge events: conclusions from satellite remote sensing and concurrent flood-plume sampling, Mar. Freshwater Res., 61, 651-664, doi:10.1071/MF08030, 2010.

Castellarin, A. and Vai, G. B.: Guida alla Geologia del Sudalpino Centro-Oriental, Guide Geologiche Regionali., Soc. Geol. Ital., Bologna, 1-22, 1982.

Chang, G. C., Dickey, T. D., Schofield, O. M., Weidemann, A. D., Boss, E., Pegau, W. S., Moline, M. A., and Glenn, S. M.: Nearshore physical processes and bio-optical properties in the New York Bight, J. Geophys. Res., 107, 3133, doi:3110.1029/2001JC001018, 2002.

Cozzi, S. and Giani, M.: River water and nutrient discharges in the Northern Adriatic Sea: current importance and long term changes,, Cont. Shelf Res., 31, 1881-1893, doi:10.1016/j.csr.2011.08.010, 2011.

Degobbis, D., Precali, R., Ivancic, I., Smodlaka, N., Fux, D., and Kveder, S.: Long-term changes in the northern Adriatic ecosystem related to anthropogenic eutrophication, Int. J. Environ. Poll., 13, 495-533, doi:10.1504/IJEP.2000.002332, 2000.

D’Sa, E. J., Miller, R., and McKee, B. A.: Suspended particulate matter dynamics in coastal waters from ocean color: application to the northern Gulf of Mexico, Geophys. Res. Lett., 34, L23611, doi:10.1029/2007GL031192, 2007.

Devlin, M. J. and Schaeffelke, B.: Spatial extent of riverine flood plumes and exposure of marine ecosystems in the Tully coastal region, Great Barrier Reef., Mar. Freshwater Res., 60, 11091122, doi:10.1071/MF08343, 2009.

Dickey, T.: Emerging ocean observations for interdisciplinary data assimilation systems, J. Marine Syst., 40-41, doi:10.1016/S0924-7963(03)00011-3, 2003.

Dinelli, E. and Lucchini, F.: Sediment supply to the Adriatic sea basin from the Italian rivers: geochemical features and environmental constraints, Giornale Geol., 61, 121-135, 1999.

Dogliotti, A., Ruddick, K., Nechad, B., Doxaran, D., and Knaeps, E.: A single algorithm to retrieve turbidity from remotely-sensed data in all coastal and estuarine waters, Remote Sens. Environ., 156, 157-168, doi:10.1016/j.rse.2014.09.020, 2015.

Falcieri, F. M., Benetazzo, A., Sclavo, M., Russo, A., and Carniel, S.: Po River plume pattern variability investigated from model data, Cont. Shelf Res., Cont. Shelf Res., 87, 84-95, doi:10.1016/j.csr.2013.11.001, 2014.

Falcini, F., Khan, N. S., Macelloni, L., Horton, B. P., Lutken, C. B., McKee, K. L., Santoleri, R., Colella, S., Li, C., Volpe, G., D'Emidio, M., Salusti, A., and Jerolmack, D. J.: Linking the historic 2011 Mississippi River flood to coastal wetland sedimentation, Nat. Geosci., 5, 803-807, doi:10.1038/ngeo1615, 2012.

Fisher, J. I. and Mustard, J. F.: High spatial resolution sea surface climatology from Landsat thermal infrared data, Remote Sens. Environ., 90, 293-307, doi:10.1016/j.rse.2004.01.008, 2004.

Franz, B. A., Bailey, S. W., Kuring, N., and Werdell, P. J.: Ocean color measurements with the Operational Land Imager on Landsat-8: implementation and evaluation in SeaDAS, J. Appl. Remote Sens., 9, 096070, doi:10.1117/1.JRS.9.096070, 2015.
Gacic, M., Marullo, S., Santoleri, R., and Bergamasco, A.: Analysis of the seasonal and interannual variability of the sea surface temperature field in the Adriatic Sea from AVHRR data (1984-1992), J. Geophys. Res.-Oceans, 102, 22937-22946, doi:10.1029/97jc01720, 1997.

Geyer, W. R., Hill, P. S., and Kineke, G. C.: The transport, transformation and dispersal of sediment by buoyant coastal flows, Cont. Shelf Res., 24, 927-949, doi:10.1016/j.csr.2004.02.006, 2004.

Hellweger, F. L., Schlosser, P., Lall, U., and Weissel, J. K.: Use of satellite imagery for water quality studies in New York Harbor, Estuarine, Coastal and Shelf Science, 61, 437-448, 2004.

Hestir, E. L., Brando, V. E., Bresciani, M., Giardino, C., Matta, E., Villa, P., and Dekker, A. G.: Measuring freshwater aquatic ecosystems: The need for a hyperspectral global mapping satellite mission, Remote Sens. Environ., 167 181-195, doi:10.1016/j.rse.2015.05.023, 2015

Hetland, R. D.: Relating River Plume Structure to Vertical Mixing,, J. Phys. Oceanogr., 35, 1667-1688, doi:10.1175/JPO2774.1, 2005.

Hickey, B. M., Geier, S. L., Kachel, N. B., and MacFadyen, A.: A bi-directional river plume: The Columbia in summer, Cont. Shelf Res., 25, 1631-1656, doi:10.1016/j.csr.2005.04.010, 2005.

Horner-Devine, A. R., Hetland, R. D., and MacDonald, D. G.: Mixing and Transport in Coastal River Plumes, Annu. Rev. Fluid Mech, 47, 569-594, doi:10.1146/annurev-fluid-010313-141408, 2015.

Irons, J. R., Dwyer, J. L., and Barsi, J. A.: The next Landsat satellite: The Landsat Data Continuity Mission, Remote Sens. Environ., 122, 11-21, doi:10.1016/j.rse.2011.08.026, 2012.

Janssen, P. A. E. M., Abdalla, S., Hersbach, H., and Bidlot, J. R.: Error estimation of buoy, satellite, and model wave height data, J. Atmos. Ocean. Tech., 24, 1665-1677, doi:10.1175/JTECH2069.1, 2007.

Margvelashvili, N., Andrewartha, J., Herzfeld, M., Robson, B., and Brando, V. E.: Satellite data assimilation and estimation of a $3 \mathrm{~d}$ coastal sediment transport model using errorsubspace emulators, Environ. Modell. Softw., 40, 191-201, doi:10.1016/j.envsoft.2012.09.009, 2013.

Marini, M., Jones, B. H., Campanelli, A., Grilli, F., and Lee, C. M.: Seasonal variability and Po River plume influence on biochemical properties along western Adriatic coast, J. Geophys. Res.Oceans, 113, C05S90, doi:10.1029/2007JC004370, 2008.

Melin, F., Vantrepotte, V., Clerici, M., D'Alimonte, D., Zibordi, G., Berthon, J.-F., and Canuti, E.: Multi-sensor satellite time series of optical properties and chlorophyll-a concentration in the Adriatic Sea, Prog. Oceanogr., 9, 229-244, doi:10.1016/j.pocean.2010.12.001, 2011.

Montanari, A.: Hydrology of the Po River: looking for changing patterns in river discharge, Hydrol. Earth Syst. Sci., 16, 37393747, doi:10.5194/hess-16-3739-2012, 2012.

Mouw, C. B., Greb, S., Aurin, D., DiGiacomo, P. M., Z. Lee, Twardowski, M., Binding, C., C. Hu, Ma, R., Moore, T., Moses, W., and Craig, S. E.: Aquatic color radiometry remote sensing of coastal and inland waters: Challenges and recommendations for future satellite missions, Remote Sens. Environ., 160, 15-30, doi:10.1016/j.rse.2015.02.001, 2015.

Nof, D. and Pichevin, T.: The ballooning of outflows, J. Phys. Oceanogr., 31, 3045-3058, doi:10.1175/15200485(2001)031<3045:Tboo>2.0.Co;2, 2001. 
Otero, P., Ruiz-Villarreal, M., and Peliz, Á.: Variability of river plumes off North- west Iberia in response to wind events, J. Mar. Syst., 72, 238-255, doi:10.1016/j.jmarsys.2007.05.016, 2008.

Otero, P., Ruiz-Villarreal, M., and Peliz, Á.: River plume fronts off NW Iberia from satellite observations and model data., J. Mar. Sci, 66, 1853-1864, doi:10.1093/icesjms/fsp156, 2009.

Pahlevan, N., Lee, Z., Wei, J., Schaaf, C. B., Schott, J. R., and Berk, A.: On-orbit radiometric characterization of OLI (Landsat-8) for applications in aquatic remote sensing, Remote Sens. Environ., 154, 272-284, doi:10.1016/j.rse.2014.08.001, 2014.

Palacios, S. L., Peterson, T. D., and Kudela, R. M.: Development of synthetic salinity from remote sensing for the Columbia River plume, J. Geophys. Res., 114, C00B05, doi:10.1029/2008JC004895, 2009.

Pietrzak, J. D., Boer, G. J. d., and Eleveld, M. A.: Mechanisms controlling the intra-annual mesoscale variability of SST and SPM in the southern North Sea, Cont. Shelf Res., 31, 594-610, doi:10.1016/j.csr.2010.12.014, 2011.

Pigorini, B.: Sources and dispersion of recent sediments of the Adriatic Sea, Mar. Geol., 3, 187-229, doi:10.1016/00253227(68)90031-5, 1968.

Piovan, S., Mozzi, P., and Stefani, C.: Bronze Age paleohydrography of the southern Venetian Plain, Geoarchaeology, 25, 6-35, doi:10.1002/gea.20300, 2010.

Raicich, F.: Note on the flowrates of the Adriatic rivers. Tech. Rep. RF 02/94, CNR Istituto Sperimentale Talassografico, Trieste, Italy, 8, 1994.

Robinson, I. S.: Discovering the Ocean from Space The Unique Applications of Satellite Oceanography Springer, Heidelberg, 638 pp., 2010.

Russo, A., Carniel, S., and Benetazzo, A.: Support for ICZM and MSP in the Adriatic Sea region., Sea Technol., 54, 27-35, 2013 a.

Russo, A., Coluccelli, A., Carniel, S., Benetazzo, A., Valentini, A., Paccagnella, T., Ravaioli, M., and Bortoluzzi, G.: Operational models hierarchy for short term marine predictions: the Adriatic Sea example, MTS/IEEE OCEANS, Bergen, 1-6, 2013b.

Schroeder, T., Devlin, M. J., Brando, V. E., Dekker, A. G., Brodie, J. E., Clementson, L. A., and McKinna, L.: Interannual variability of wet season freshwater plume extent into the Great Barrier Reef lagoon based on satellite coastal ocean colour observations, Mar. Pollut. Bull., 65, 210-223, doi:10.1016/j.marpolbul.2012.02.022, 2012.

Sclavo, M., Benetazzo, A., Carniel, S., Bergamasco, A., Falcier, F. M., and Bonaldo, D.: Wave-current interaction effect on sediment dispersal in a shallow semi-enclosed basin, J. Coastal Res., 65, 1587-1592, doi:10.2112/SI65-268.1, 2013.

Simpson, J. H.: Physical processes in the ROFI regime, J. Mar. Syst., 12, 3-15, doi:10.1016/S0924-7963(96)00085-1, 1997.

Solidoro, C., Bastianini, M., Bandelj, V., Codermatz, R., Cossarini, G., Canu, D. M., Ravagnan, E., Salon, S., and Trevisani, S.: Current state, scales of variability, and trends of biogeochemical properties in the northern Adriatic Sea, J. Geophys. Res.-Oceans, 114, C07S91, doi:10.1029/2008JC004838, 2009.

Spillman, C. M., Imberger, J., Hamilton, D. P., Hipsey, M. R., and Romero, J. R.: Modelling the effects of Po River discharge, internal nutrient cycling and hydrodynamics on biogeochemistry of the northern Adriatic Sea, J. Mar. Syst., 68, 167-200, doi:10.1016/j.jmarsys.2006.11.006, 2007.
Stanev, E. V., Schulz-Stellenfleth, J., Staneva, J., Grayek, S., Seemann, J., and Petersen, W.: Coastal observing and forecasting system for the German Bight - estimates of hydrophysical states, Ocean Sci., 7, 569-583, doi:10.5194/os-7-569-2011, 2011.

Staneva, J., Stanev, E. V., Wolff, J.-O., Badewien, T. H., Reuter, R., Flemming, B., Bartholoma, A., and Bolding, K.: Hydrodynamics and sediment dynamics in the German Bight. A focus on observations and numerical modeling in the East Frisian Wadden Sea, Cont. Shelf Res., 29, 302-319, doi:10.1016/j.csr.2008.01.006, 2009.

Storey, J., Choate, M., and Moe, D.: Landsat 8 Thermal Infrared Sensor Geometric Characterization and Calibration, Remote Sens.-Basel, 6, 11153-11181, doi:10.3390/rs61111153, 2014.

Syvitski, J. P., Kettner, A. J., Correggiari, A., and Nelson, B. W.: Distributary channels and their impact on sediment dispersal, Mar. Geol., 222, 75-94, doi:10.1016/j.margeo.2005.06.030, 2005.

Tesi, T., Miserocchi, S., Goñi, M. A., Turchetto, M., Langone, L., De Lazzari, A., Albertazzi, S., and Correggiari, A.: Influence of distributary channels on sediment and organic matter supply in event-dominated coastal margins: the Po prodelta as a study case, Biogeosciences, 8, 365-385, doi:10.5194/bg-8-365-2011, 2011.

Ullman, D. S. and Cornillon, P. C.: Satellite-derived sea surface temperature fronts on the continental shelf off the northeast US coast, J. Geophys. Res., 104C, 23459-23478, doi:10.1029/1999JC900133, 1999.

Vanhellemont, Q. and Ruddick, K.: Turbid wakes associated with offshore wind turbines observed with Landsat 8, Remote Sens. Environ., 145, 105-115, doi:10.1016/j.rse.2014.01.009, 2014.

Vanhellemont, Q. and Ruddick, K.: Advantages of high quality SWIR bands for ocean colour processing: Examples from Landsat-8, Remote Sens. Environ, 161, 89-106, doi:10.1016/j.rse.2015.02.007, 2015 .

Vantrepotte, V., Loisel, H., Dessailly, D., and Mériaux, X.: Optical classification of contrasted coastal waters, Remote Sens. Environ., 123, 306-323, doi:10.1016/j.rse.2012.03.004, 2012.

Warner, J. C., Sherwood, C. R., Signell, R. P., Harris, C., and Arango, H. G.: Development of a three-dimensional, regional, coupled wave, current, and sediment-transport model, Comput. Geosci., 34, 1284-1306, doi:10.1016/j.cageo.2008.02.012, 2008.

Zasso, M. and Settin, T.: Sulla ripartizione delle portate del Po tra i vari rami e le bocche a mare del delta: esperienze storiche e nuove indagini all'anno 2011 Relazione n. 02/12, ARPAV Dipartimento Regionale Per La Sicurezza Del Territorio, Belluno, Italy, 1-47, 2012 (in Italian).

Zavatarelli, M., Raicich, F., Bregant, D., A. Russo, and Artegiani, A.: Climatological biogeochemical characteristics of the Adriatic Sea, , J. Mar. Syst., 18, 227-263, doi:10.1016/S09247963(98)00014-1, 1998. 